\title{
Science e-Module Based on Scientific Approach Using Kvisoft Flipbook on Temperature and Heat Materials in Class VII Junior High School
}

\author{
Alya Armani ${ }^{* 1)}$, M. Rahmad ${ }^{2)}$, Zulhelmi $^{3)}$ \\ ${ }^{1,2,3)}$ Physics Education,University of Riau \\ e-mail: ${ }^{* 1)}$ alyaarmani243@gmail.com \\ m.rahmad@lecturer.unri.ac.id \\ emi_zain@yahoo.co.id
}

\begin{abstract}
The era of the industrial revolution 4.0 requires a teacher must be able to keep up with the era to create interesting learning and easy for students to understand. In addition, the Covid-19 pandemic requires virtual learning from home. We need a learning resources, one of which is e-modules in the learning process. This research purpose to develop student learning resources in the form of an e-module temperature and heat based on a scientific approach by the Kvisoft Flipbook in e-learning. This research uses the type of R\&D (Research and Development) with the ADDIE model which only applies 4 steps, there are analysis, design, development, and evaluation steps. The data required is in the form of quantitative data, namely 1) questionnaire respondent data about the need for learning resources that are distributed to students, and 2) data on the e-module validation assessment score by the validator. Research instruments used were questionnaires and e-module validation sheets. Data were analyzed descriptively to determine the validity of the e-module. The results showed that the average score for the validation of the entire e-module was declared valid based on aspects of content, presentation, language, and graphics with a high category of 3.46. Thus the science e-module based on a scientific approach using the kvisoft flipbook on temperature and heat material has been successfully developed with valid criteria and is suitable for use as a learning resource in online science learning in Class VII junior high school.
\end{abstract}

Keywords: science e-module, scientific approach, kvisoft flipbook, temperature and heat. 


\title{
E-Modul IPA Berbasis Pendekatan Saintifik Menggunakan Kvisoft Flipbook pada Materi Suhu dan Kalor di Kelas VII SMP
}

\author{
Alya Armani: ${ }^{* 1)}$, M. Rahmad ${ }^{2)}$, Zulhelmi $^{3)}$ \\ ${ }_{1,2,3)}$ Pendidikan Fisika, Universitas Riau
}

\begin{abstract}
Abstrak
Era revolusi industri 4.0 mengharuskan seorang guru mampu mengikuti perkembangan zaman agar tercipta pembelajaran yang menarik dan mudah dipahami siswa. Disamping itu, adanya wabah Covid-19 menjadikan pembelajaran secara daring dari rumah. Dalam proses pembelajaran tersebut tentunya diperlukan sumber belajar, salah satunya e-modul. Tujuan dari penelitian ini yaitu untuk mengembangkan sumber belajar siswa berupa e-modul suhu dan kalor berbasis pendekatan saintifik berbantuan kvisoft flipbook pada pembelajaran daring. Penelitian ini menggunakan jenis R\&D (Research and Development) dengan model ADDIE yang hanya menerapkan 4 tahap yaitu tahap analisis, perancangan, pengembangan, dan tahap evaluasi. Data yang diperlukan berupa data kuantitatif yaitu: 1) data responden angket tentang keperluan sumber belajar yang disebarkan ke siswa, dan 2) data skor penilaian validasi e-modul oleh validator. Instrumen pengumpul data penelitian ini berupa angket dan lembar validasi e-modul. Data dianalisis secara deskriptif untuk mengetahui validitas dari e-modul. Hasil penelitian didapatkan skor rata-rata validasi keseluruhan e-modul dinyatakan valid berdasarkan aspek isi, penyajian, kebahasaan dan kegrafisan dengan kategori tinggi yaitu 3,46. Dengan demikian e-modul IPA berbasis pendekatan saintifik menggunakan kvisoft flipbook pada materi suhu dan kalor berhasil dikembangkan dengan kriteria valid dan layak digunakan sebagai sumber belajar dalam pembelajaran daring IPA di Kelas VII SMP.
\end{abstract}

Kata Kunci: e-modul IPA, pendekatan saintifik, kvisoft flipbook, suhu dan kalor.

\section{Pendahuluan}

Era revolusi industri 4.0 telah dirasakan oleh seluruh dunia termasuk Indonesia. Melalui Kemenristekdikti mengatakan bahwa pada era ini pekerjaan di Indonesia $75 \%$ melibatkan kemampuan sains, teknologi, pendidikan, dan internet of things (Kemenristekdikti, 2018). Perkembangan pendidikan ini tentunya seiring dengan perkembangan teknologi informasi dan komunikasi. Menurut Nina (2016) untuk mewujudkan pembelajaran yang mudah dipahami dan menarik bagi siswa, seorang guru harus mampu mengikuti perkembangan zaman.

Guru dapat memanfaatkan perkembangan teknologi ini pada proses pembelajaran, seperti media pembelajaran, khususnya pada pembelajaran fisika yang beragam dapat digunakan saat proses belajar mengajar. Disamping itu, munculnya pembelajaran e-learning yang menggunakan ICT dapat diinovasikan sedemikian rupa, sehingga pembelajaran lebih terpusat kepada siswa, karena tidak lagi guru yang harus menerangkan materi pelajaran sepenuhnya, tetapi siswa dapat belajar sambil berkreasi (Indah et al., 2019).

Terlebih lagi adanya wabah seperti pandemi Covid-19 atau SARS-Cov-2 yang melanda manusia di Dunia, mengharuskan pembelajaran dilakukan dalam jaringan (daring) menggunakan e-learning. Pernyataan ini didukung Kemendikbud yang mengeluarkan surat edaran, dirilis pada 24 Maret 2020 tentang pelaksanaan kebijakan pendidikan dalam masa darurat penyebaran Covid-19. Dalam surat edaran tersebut dijelaskan bahwa proses pembelajaran di sekolah dan perguruan tinggi di Indonesia dilakukan dengan pembelajaran dari rumah melalui pembelajaran dalam jaringan (Wahyu, 2020).

Proses belajar mengajar membutuhkan berbagai cara yang efektif. Salah satunya mengurangi sumber belajar dari buku agar siswa tidak merasa bosan, untuk itu siswa dapat menggunakan modul interaktif berbasis ICT bagi menunjang pembelajaran dari rumah agar mengurangi rasa bosan tersebut, dan diharapkan dapat menambah ketertarikan belajar dan menambah kepahaman terhadap konsep fisika, 
sehingga kesulitan belajar fisika dapat teratasi (Nurita, 2013).

Berdasarkan paparan yang telah dijabarkan, maka diperlukan adanya media pembelajaran yang tepat dan direncanakan dengan baik, serta dapat menunjang proses pembelajaran daring. Untuk itu perlu dibuat sumber belajar berbais ICT atau modul elektronik yang selanjutnya disingkat menjadi e-modul, dimana e-modul ini diharapkan menjadi solusi yang tepat untuk memudahkan dalam mempelajari materi Suhu dan Kalor di SMP secara daring. Sukendro et al. (2020) mendapatkan bahwa penggunaan e-learning selama pandemi covid19 telah diterapkan di berbagai negara. Menurut Seprida (2015) media pembelajaran e-modul termasuk ke dalam jenis fully online e-learning format, dimana kegiatan proses belajar mengajar secara menyeluruh dilakukan online (daring), yang dihubungkan dengan Learning Management System (LMS). David \& Anass (2020) menjelaskan bahwa penerapan mobile learning dapat diterima oleh siswa, guru, dan orang tua baik di perkotaan maupun di daerah pedesaan, karena pada umumnya mereka sudah memiliki perangkat elektronik sehingga yang dapat mengakses e-modul tersebut.

E-modul sebagai sumber atau media pembelajaran daring dikembangkan dengan menggunakan aplikasi kvisoft flipbook, sebuah sistem pengajaran yang menyediakan materi pembelajaran yang dapat diakses melalui perangkat elektronik yang dimiliki siswa. Kvisoft flipbook merupakan software dibawah lisensi kvisoft corporation yang berdiri pada tahun 2014. Menurut Hidayatullah (2016) kvisoft flipbook adalah aplikasi pengembang media pembelajaran berbentuk buku digital dengan mengintegrasikan gambar yang bervariasi, teks, audio, dan audiovisual, sehingga sangat cocok untuk membantu siswa dalam belajar daring. Hasil kajian pengembangan media pembelajaran menggunakan aplikasi kvisoft flipbook yang dilakukan Desi et al. (2017), menyebutkan bahwa pengembangan media pembelajaran tersebut dapat dijadikan sebagai bahan ajar, karena telah memiliki kategori valid. Untuk itu penggunaan aplikasi kvisoft flipbook sangat berperan besar dalam pembuatan e-modul. Keunggulan dari media pembelajaran ini adalah sebagai sumber belajar daring maupun luring bagi siswa yang dibantu dengan penggunaan perangkat elektronik siswa itu sendiri, serta didesain dengan bentuk yang menarik, baik visual maupun audiovisual (video), yang dapat memperjelas visualisasi pembelajaran sehingga siswa tidak jenuh mempelajari materi yang disajikan dalam emodul tersebut (Hidayatullah, 2016).

Menurut Permendikbud Nomor 103 Tahun 2014, menjelaskan bahwa pendekatan saintifik terdiri dari kegiatan mengamati, menanya, mengumpulkan informasi atau mencoba, menalar atau mengasosiasi, dan mengkomunikasikan (Kemendikbud, 2014). Oleh karena itu, e-modul ini dikembangkan menggunakan pendekatan saintifik yang mengacu pada kurikulum 2013. Majid \& Rochman dalam Siti et al. (2018) mengungkapkan bahwa pengetahuan siswa dapat dibangun dengan metode ilmiah melalui langkah-langkah saintis yang ada pada pendekatan saintifik.

Diharapkan dengan dihasilkannya emodul ini, dapat memudahkan guru sebagai fasilitator dalam menyampaikan pembelajaran secara daring dengan tetap menerapkan pendekatan saintifik menggunakan kurikulum 2013. Zaharah et al. (2017) mengatakan bahwa siswa dapat terlibat langsung dalam menemukan fakta dan menggali konsep khususnya pada pembelajaran IPA fisika melalui pendekatan ini. Selain itu, penelitian Anggraini (2019) mengungkapkan bahwa penggunaan e-modul pada pembelajaran daring dinilai efektif dan efisien, karena e-modul IPA fisika yang diintegrasikan dengan keterampilan proses sains. Untuk itu dapat diketahui, bahwa penggunaan e-modul IPA fisika dapat meningkatkan kemampuan siswa dibandingkan dengan pembelajaran konvensional.

Berdasarkan uraian tersebut, maka dalam kajian ini menarik untuk dikembangkan emodul IPA berbasis pendekatan saintifik menggunakan kvisoft flipbook pada pembelajaran IPA materi Suhu dan Kalor SMP dengan menguji validasi media tersebut, agar media tersebut dapat digunakan oleh guru dan siswa SMP sebagai media pembelajaran daring ataupun secara luring.

\section{Metode Penelitian}

Penelitian pengembangan e-modul IPA fisika berbasis pendekatan saintifik menggunakan kvisoft flipbook sebagai media pembelajaran fisika pada materi suhu dan kalor, dilaksanakan di Laboratorium Pengembangan 
Media Pembelajaran Fisika, Jurusan PMIPA FKIP Universitas Riau. Penelitian dilaksanakan pada semester ganjil tahun ajaran 2020/2021.

Jenis penelitian yang digunakan adalah $\mathrm{R} \& \mathrm{D}$ (Research and Development) dengan model ADDIE sebagai model pengembangan yang terdiri dari lima tahap yaitu Analysis (analisis), Design (perancangan), Development (pengembangan), Implementation (implementasi), dan Evaluation (evaluasi). Tahap evaluasi dalam model ADDIE dilakukan pada setiap satu bagian tahapan dan juga dapat dilakukan evaluasi setelah semua tahapan selesai (Robert, 2009). Tahap implementasi tidak dilakukan pada kajian ini, sehingga hanya sampai pada tahap pengembangan sesuai keperluan.

Jenis data yang diperoleh yaitu data kuantitatif, menggunakan skor penilaian dari lembar validasi yang diisi oleh validator dan data angket respon siswa yang disebarkan. Instrumen pengumpul data yang dipakai adalah angket siswa, terkait kebutuhan e-modul pada pembelajaran IPA fisika, untuk mengetahui permasalahan pada pembelajaran daring. Terdapat 11 pernyataan yang dikemas dalam google form dan diberikan kepada 30 orang siswa sebagai responden. Selain itu, terdapat juga lembar validasi pengembangan e-modul yang mengacu pada panduan yang dikeluarkan Depdiknas dengan beberapa modifikasi sesuai spesifikasi e-modul yang diperlukan (Depdiknas, 2008).

Teknis analisa data yang digunakan yaitu dengan menjumlahkan skor tiap indikator angket validasi. Kategori penilaian angket oleh validator menggunakan ketentuan menurut Tabel 1.

Tabel 1. Skor penilaian angket validasi

\begin{tabular}{cc}
\hline Skor & Kategori \\
\hline 4 & Sangat Baik \\
3 & Baik \\
2 & Kurang \\
1 & Sangat Kurang \\
\hline
\end{tabular}

Sumber: adaptasi dari (Riduwan, 2015).

Untuk menghitung nilai rata-rata tiap indikator angket validasi sesuai persamaan (1).

$$
\overline{\mathrm{x}}=\frac{\text { ju } \quad \text { s } \quad \text { it } \quad v}{\text { ju } \quad \mathrm{v}}
$$

Kemudian menentukan kategori kevalidan dari skor rata-rata tiap item berdasarkan kategori penilaian seperti pada Tabel 2 .

Tabel 2. Kategori penilaian

\begin{tabular}{rc}
\hline Skor rata-rata & Kategori \\
\hline $3,50 \leq \bar{x} \leq 4,00$ & Sangat tinggi \\
$3,00 \leq \bar{x}<3,50$ & Tinggi
\end{tabular}

Sumber: adaptasi dari (Riduwan, 2015).

Berdasarkan hasil pengkategorian, maka dilakukan penarikan kesimpulan dengan cara menganalisis setiap komponen penilaian emodul. E-modul dinyatakan valid apabila setiap komponen penilaian validasi memiliki skor minimal 3.00 dan rata-rata skor validasi setiap komponen memiliki skor minimal 3.00. Apabila salah satu dari item indikator angket validasi berada pada interval skor $<3.00$, maka kategori tersebut dinyatakan tidak valid dan harus dilakukan perbaikan atau revisi pada indikator tersebut yang selanjutnya divalidasi kembali sampai memenuhi kategori valid.

\section{Hasil dan Pembahasan}

Tahap Analisis (Analysis)

Analisis kebutuhan meliputi analisis tugas terkait analisis struktur materi, konsep, dan tujuan pembelajaran melalui studi literatur untuk mengidentifikasi materi yang relevan dengan pengembangan media pembelajaran. Materi IPA di SMP menjadi materi yang dipilih pada penelitian ini, mengacu kepada kajian Napsawati (2020) yang menemukan bahwa pembelajaran IPA di SMP secara daring menimbulkan masalah baru dalam proses pembelajaran seperti guru kesulitan dalam mentransfer materi pelajaran kepada siswa. Untuk itu dipilihlah materi Suhu dan Kalor di SMP kelas VII pada semester ganjil.

Selanjutnya analisis keperluan, diperoleh dari penyebaran angket kepada siswa untuk memperoleh informasi, dengan memberikan 11 pernyataan yang disebar dalam aplikasi google form. Angket diisi oleh 30 orang siswa sebagai responden yang hasilnya menurut Gambar 1 . 


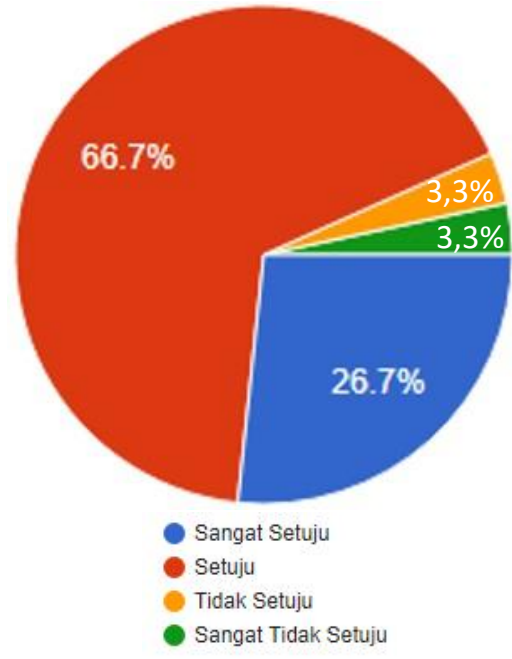

Gambar 1. Analisis keperluan terhadap respon siswa.

Berdasarkan Gambar 1 diketahui persentase hasil angket yang disebar menunjukkan 93,4\% responden menyatakan memerlukan sumber belajar pada pembelajaran daring yang menyajikan gambar, animasi, dan video dirangkum dalam e-modul berbasis pendekatan saintifik pada materi suhu dan kalor di SMP. Hanya $6,6 \%$ responden yang merasa tidak memerlukan, sehingga data ini menjadi salah satu dasar pentingnya pengembangan e-modul.

Tahap Perancangan (Design)

Setelah melewati tahap analisis, pembuatan e-modul dilanjutkan ke tahap perancangan yang ditunjukkan pada flowchart Gambar 2.

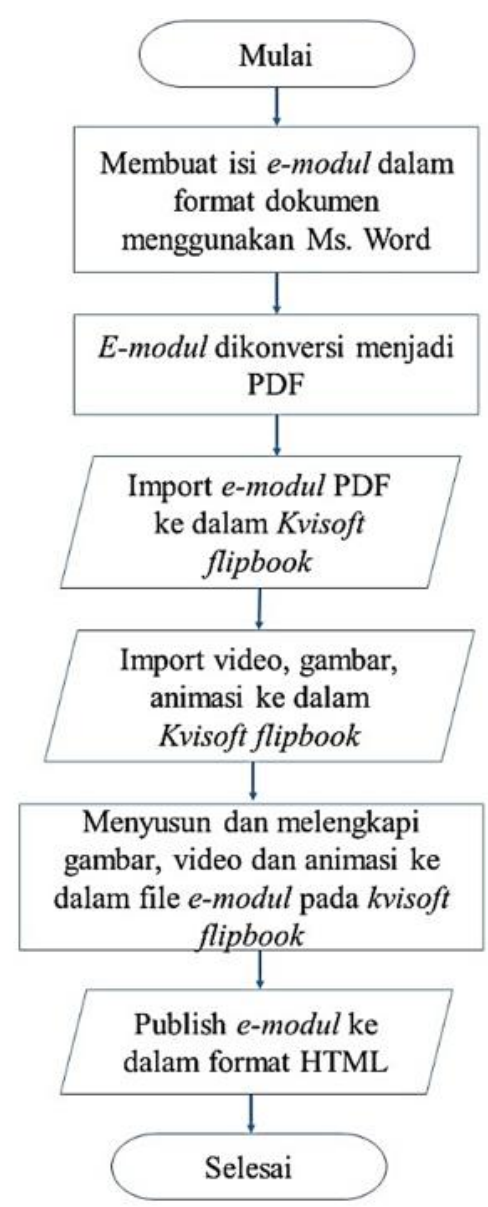

Gambar 2. Flowchart perancangan e-modul.

Melalui Gambar 2 dapat dilihat bahwa perancangan e-modul dikembangkan melalui tahap mulai sampai pada bagian akhir (selesai), sebagaimana tertera pada flowchart. Pada tahap ini juga dibuat garis-garis besar atau outline emodul seperti pada Tabel 3.

Tabel 3. Bagian outline e-modul

\begin{tabular}{|c|c|}
\hline Bagian & Keterangan \\
\hline Pembuka & $\begin{array}{l}\text { Bagian ini berisikan halaman sampul depan, kata pengantar, daftar isi, petunjuk } \\
\text { penggunaan } e \text {-modul, tujuan pembelajaran, dan indikator pembelajaran. }\end{array}$ \\
\hline $\begin{array}{l}\text { Kegiatan } \\
\text { inti }\end{array}$ & $\begin{array}{l}\text { Bagian ini berisikan materi yang akan diajarkan dan bagian ini disusun menjadi } \\
\text { dua bagian pokok bahasan materi yaitu: } \\
\text { - Suhu dan perubahannya } \\
\text { - Kalor dan perubahannya. } \\
\text { Materi memuat pendahuluan, kegiatan inti, dan penutup. Pendahuluan memuat } \\
\text { pertanyaan sebagai pemantik berpikir awal yang disajikan dalam bentuk } \\
\text { peristiwa menarik berkaitan dengan kehidupan sehari-hari. Kegiatan inti terdiri } \\
\text { dari materi berupa teks, video, gambar dan animasi dilengkapi pernyataan yang } \\
\text { memacu rasa ingin tahu siswa. Penutup terdiri dari rangkuman dan soal } \\
\text { evaluasi. }\end{array}$ \\
\hline
\end{tabular}

Penutup Bagian penutup berisikan daftar pustaka dan halaman sampul belakang. 
Berdasarkan Tabel 3, menunjukkan bahwa outline e-modul terdiri atas 3 bagian yaitu bagian pembuka, kegiatan inti dan penutup. Menurut Abdullah et al. (2020), bahwa pada tahap perancangan dibuat juga rancangan instrumen penilaian berupa lembar validasi untuk diisi oleh validator saat dilakukan validasi e-modul.
Tahap Pengembangan (Development)

Tahap pengembangan dilakukan dengan merealisasikan apa yang telah dirancang pada tahap sebelumnya. Hasil tampilan awal emodul yang telah dikembangkan ditunjukkan pada Tabel 4.

Tabel 4. Tampilan e-modul dan penjelasannya

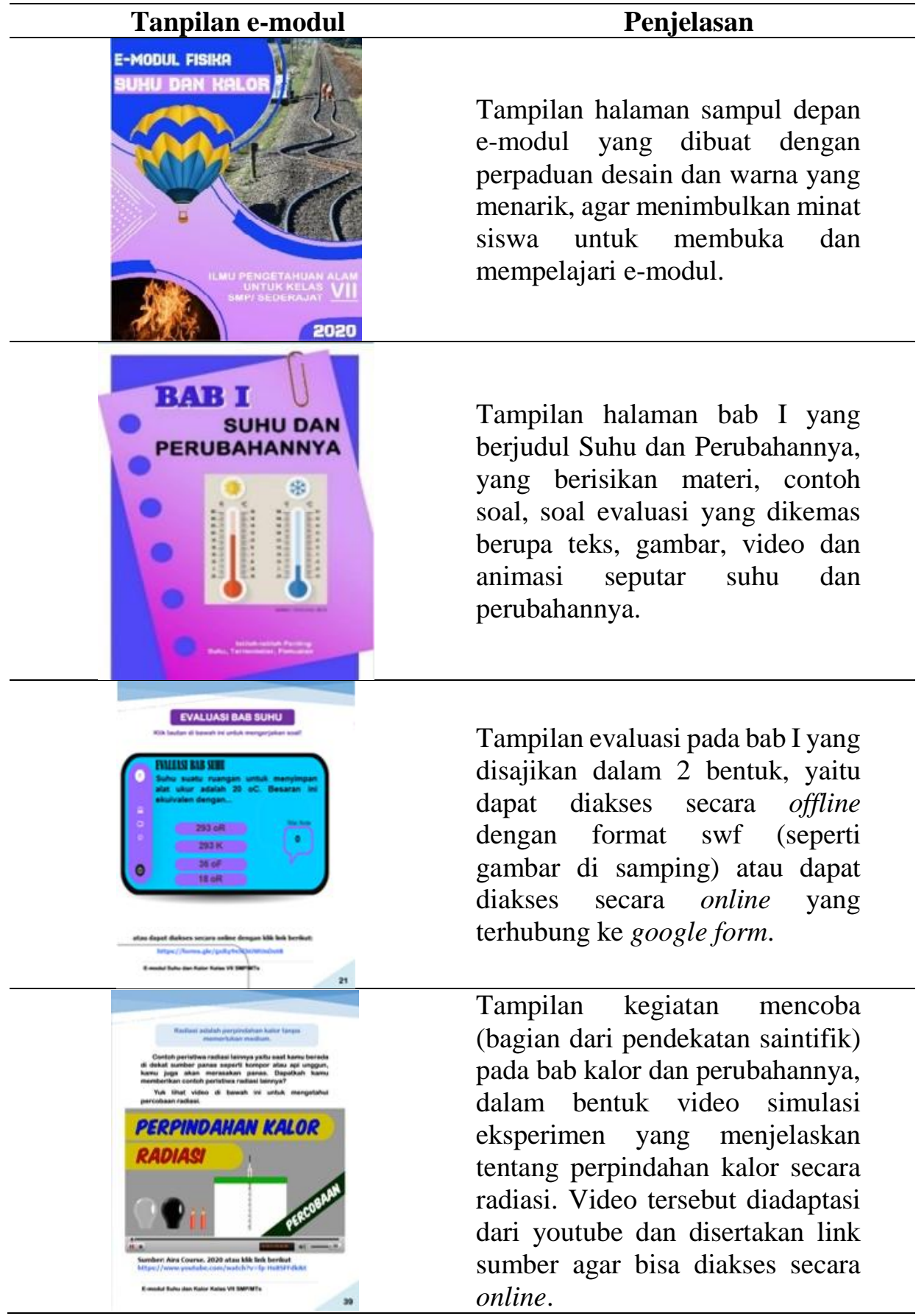




Tampilan soal latihan merupakan
bagian dari kegiatan inti materi
bab kalor dan perubahanna yaitu
"Ayo Latihan".

Berdasarkan Tabel 4, terlihat bahwa emodul dikembangkan sesuai dengan perancangan yang sebelumnya telah dibuat. Selanjutnya, e-modul divalidasi oleh validator yakni 3 orang dosen Pendidikan Fisika FKIP Universitas Riau yang ahli dibidangnya, untuk menghasilkan sebuah produk yaitu e-modul yang valid, baik dari aspek kelayakan penyajian, isi, kebahasaan, dan kegrafisan. Emodul divalidasi sebanyak 2 kali.
Hasil validasi awal e-modul menunjukkan terdapat beberapa indikator penilaian e-modul yang tergolong rendah. Untuk itu perlu dilakukan perbaikan berdasarkan masukan dan saran yang telah validator berikan untuk setiap aspek penilaian. Selanjutnya dilakukan perbaikan e-modul pada beberapa aspek sesuai Tabel 5 berikut, yang menunjukkan hasil pengembangan sebelum dan sesudah diperbaiki.

Tabel 5. Tampilan e-modul sebelum dan sesudah revisi

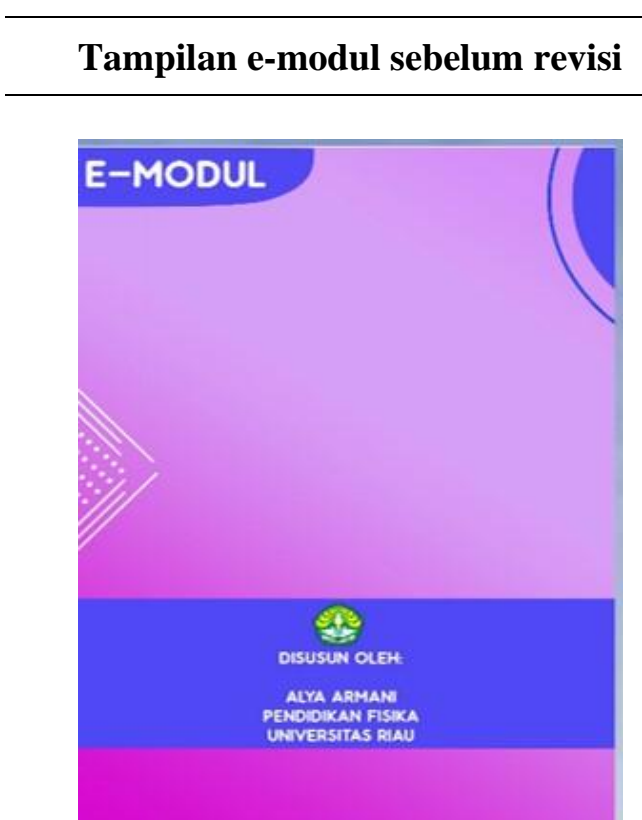

Tidak ada keterangan singkat e-modul pada halaman sampul belakang.

\section{Tampilan e-modul sesudah revisi}

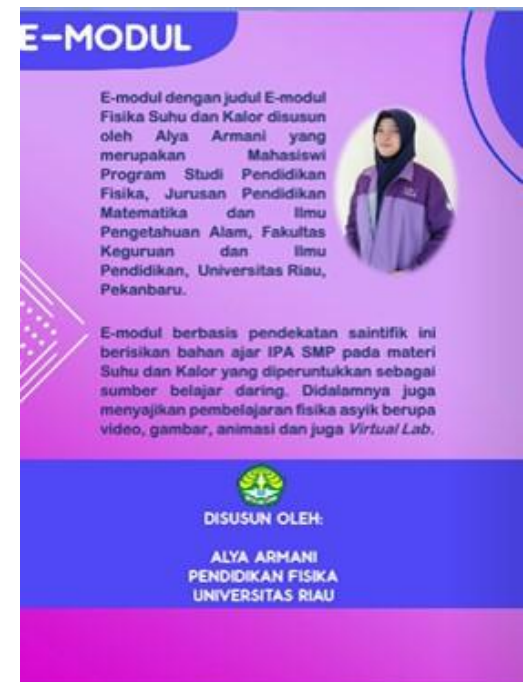

Penambahan keterangan singkat e-modul pada halaman sampul belakang. 




Pada “Ayo Latihan” siswa tidak diberi ruang untuk menjawab soal.

\section{Ayo latihan!}

1. Mengapa kabel listrik bertegangan tinggi dipasang agak kendur?

Pada suhu $0^{\circ} \mathrm{C}$, panjang sebatang besi adalah 250 $\mathrm{cm}$. Jika suhu besi dinalkkan menjadi $100^{\circ} \mathrm{C}$, ternyata panjang besi itu menjadi $250,40 \mathrm{~cm}$. Tentukan koefisien muai panjang bes/!

3. Baja pada suhu $20^{\circ} \mathrm{C}$ memilliki panjang $40 \mathrm{~cm}$. Jika koefisien mual panjang baja $0,00002 F \mathrm{C}$. Berapakah panjangnya pada setelah bertambah $70^{\circ} \mathrm{C}$

submit jawabanmu di bawah ini: submit

E-modul Suhu dan Kalor Kelas VII SMParTs

Pada “AyoLatihan” siswa diberi ruang untuk menulis jawaban yang terhubung langsung ke google classroom.



Rangkuman tidak lengkap karena tidak terdapat formula.

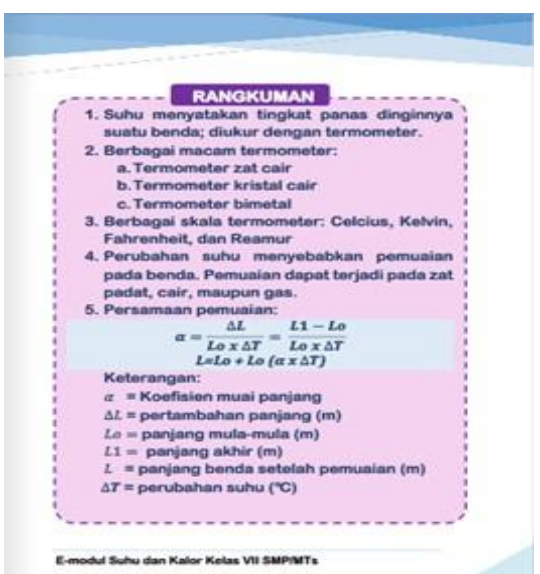

Penambahan formula pada rangkuman.

\begin{tabular}{|c|}
\hline Ayo lakukan! \\
\hline $\begin{array}{l}\text { Mengamati } \\
\text { Celupkan sendok kayu dan sendok logam pada air } \\
\text { panas. Pegang ujung kedua sendok itu. Catat apa } \\
\text { yang kamu rasakan beberapa saat kemudian. }\end{array}$ \\
\hline $\begin{array}{l}\text { Menanya } \\
\text { Berdasarkan hasil pengamatanmu, tuliskan } \\
\text { pertanyaan-pertanyaan yang ingin kamu ketahui. }\end{array}$ \\
\hline $\begin{array}{l}\text { Menalar } \\
\text { 1. Apakah jenis bahan berpengaruh terhadap } \\
\text { konduktivitas bahan? } \\
\text { 2. Coba kamu pikirkan jawaban sementaramu. }\end{array}$ \\
\hline $\begin{array}{l}\text { Mencoba } \\
\text { 1. Siapkan sendok kayu, sendok logam, dan sendok } \\
\text { plastik yang berukuran hampir sama. Tempelkan } \\
\text { paku payung pada pegangan sendok-sendok tersebut } \\
\text { dengan menggunakan mentega. } \\
\text { 2. Berdirikan sendok-sendok tersebut pada gelas } \\
\text { beker atau panci. Jika mentega meleleh, paku } \\
\text { payung akan jatuh. Coba urutkan jatuhnya paku } \\
\text { payung tersebut jika air panas dimasukkan ke dalam } \\
\text { gelas beker. } \\
\text { 3. Masukkan air panas ke dalam gelas beker tersebut. } \\
\text { Amatilah urutan jatuhnya paku payung. Apakah tiap. } \\
\text { tiap kelompok dalam kelasmu memperoleh hasil yang } \\
\text { sama? }\end{array}$ \\
\hline
\end{tabular}

Perlu ditambahkan gambar pada “Ayo Lakukan" dan juga perlu diberi ruang kepada siswa untuk menjawab pertanyaan.



Pada “Ayo Lakukan” telah ditambahkan gambar dan diberi ruang kepada siswa untuk menulis jawaban yang terhubung langsung ke Google Classroom. 
Tidak ada identitas penulis, institusi dan pembimbing pada e-modul.



Penambahan identitas penulis, institusi dan pembimbing pada e-modul.
Tabel 5 menunjukkan terdapat beberapa bagian e-modul yang telah diperbaiki berdasarkan masukan dan saran yang telah validator berikan. Adapun bagian-bagian emodul yang diperbaiki terdiri dari identitas penulis, rangkuman, halaman belakang emodul, Ayo Lakukan, Ayo Latihan, contoh soal, gambar, bagan, dan tabel. Setelah diperbaiki, e-modul kembali divalidasi oleh validator. Pada validasi akhir terdapat perubahan skor yang diberikan oleh validator. Adapun hasil validasi keseluruhan e-modul terlihat pada Gambar 3.

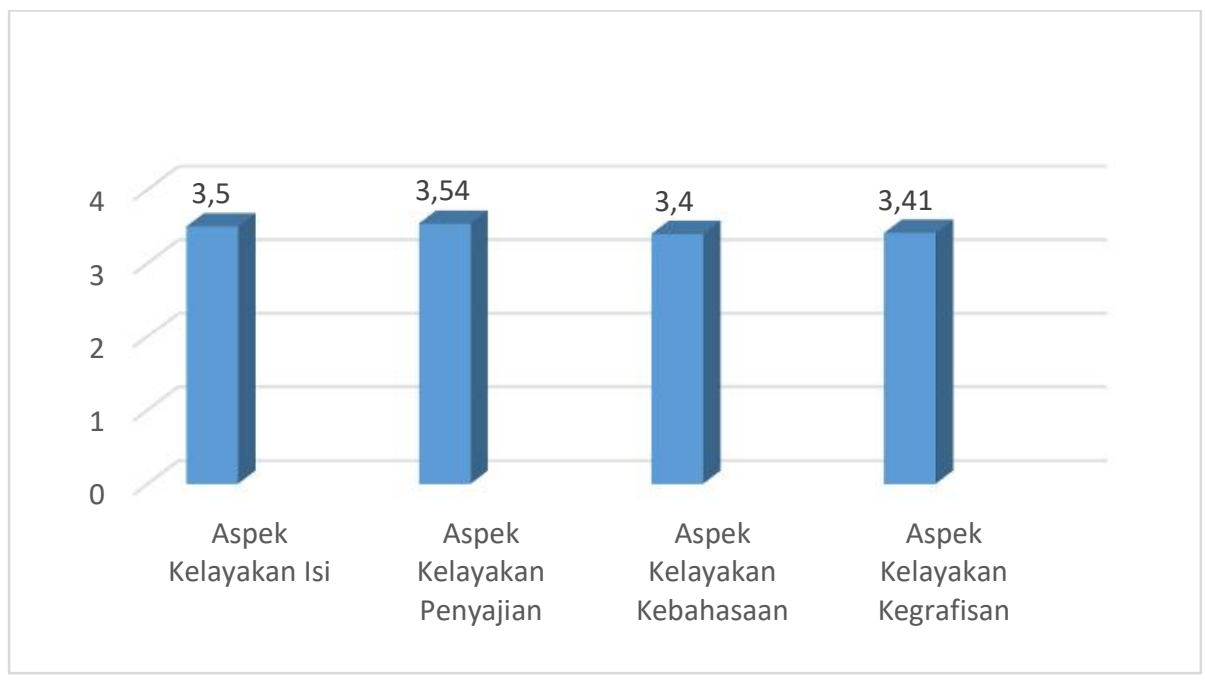

Gambar 3. Grafik skor rata-rata validasi e-modul.

Berdasarkan grafik pada Gambar 3, terlihat bahwa terdapat perubahan skor rata-rata pada masing-masing aspek penilaian. Skor rata-rata mendapatkan skor lebih tinggi pada validasi akhit. Pada validasi akhir diperoleh skor ratarata keseluruhan dengan kategori tinggi yaitu 3,46 .

Berdasarkan kategori validitas dari Riduwan (2015), dimana skor 3,46 tergolong kategori tinggi dan dinyatakan valid. Hal ini sesuai dengan penelitian pengembangan media pembelajaran menggunakan aplikasi kvisoft flipbook oleh Desi et al. (2017) yang memperoleh hasil pengembangan media pembelajaran dengan kategori valid, efektif, dan tuntas, sehingga dapat digunakan. Kajian Nurul et al. (2020) juga mendapatkan bahwa penelitian pengembangan e-modul dengan aplikasi yang sama memiliki kategori cukup baik dan sangat reliabel, sehingga e-modul layak diaplikasikan pada pembelajaran. Pernyataan ini didukung oleh Taufik (2018) mengenai kelebihan e-modul, dimana e-modul ini bisa disimpan dalam perangkat elektronik, 
sehingga bisa menjadi sumber belajar digital yang lebih baik, apabila dibandingkan dengan modul cetak pada umumnya.

Isi materi e-modul didukung oleh teori konstruktivisme yang bertujuan agar konsep baru yang ditemukan siswa nantinya dapat diterapkan dan diintegrasikan dengan konsepkonsep lainnya yang telah ditemukan. Hal ini didukung dengan penelitian Rebecca \& Jeremy (2020), yang mengatakan bahwa penggunaan emodul memungkinkan siswa untuk lebih terlibat lebih aktif dan juga terlibat dalam pembelajaran mereka sendiri dengan konten yang tersedia di e-modul.

E-modul juga dikembangkan berbasis pendekatan saintifik, yang mana bersesuaian dengan hasil kajian Dahlia et al. (2019) yang menyatakan bahwa pendekatan saintifik dalam pembelajaran e-learning lebih baik dibandingkan dengan pendekatan saintifik dalam pembelajaran konvensional. Selain itu Nur Pajr et al. (2017) mengungkapkan bahwa pemahaman konsep siswa dapat meningkat pada proses pembelajaran, karena menggunakan e-modul berbasis pendekatan saintifik. Dengan adanya pendekatan ini memberikan keterkaitan langsung kepada siswa, sehingga dapat menemukan konsep dan menggalinya berdasarkan fakta yang ditemukan (Sufairoh, 2016). Metriana (2020) mendapatkan bahwa penggunaan e-modul dalam pembelajaran daring sangat membantu guru untuk menyampaikan pembelajaran yang menarik perhatian siswa. Selain itu, penggunaan emodul interaktif merupakan metode yang efektif untuk pengajaran e-learning (Joanne $e t$ al., 2020).

E-modul yang dihasilkan dapat diakses menggunakan perangkat elektronik seperti laptop atau hand-phone dengan melakukan instalasi aplikasi e-modul terlebih dahulu ke dalam perangkat elektronik. E-modul yang dihasilkan dilengkapi dengan berbagai sumber belajar dalam bentuk teks, gambar, illustrasi, animasi, video, bersifat interaktif dan berbasis pendekatan saintifik. E-modul memenuhi kategori valid, sehingga layak digunakan sebagai sumber belajar di Kelas VII SMP pada materi suhu dan kalor. E-modul dapat digunakan baik pada masa pandemi melalui pembelajaran daring, maupun pada saat pembelajaran di luar jaringan (luring) yaitu di kelas, apabila tersedia perangkat elektronik yang memadai.

\section{Kesimpulan}

Berdasarkan hasil pengembangan e-modul dengan skor rata-rata validasi 3,46 yang mencapai kategori tinggi, maka e-modul dinyatakan valid dari aspek penyajian, isi, kebahasaan, dan kegrafisan. Oleh karena itu, emodul IPA SMP berbasis pendekatan saintifik menggunakan kvisoft flipbook pada materi suhu dan kalor, telah berhasil dikembangkan dan layak digunakan sebagai sumber belajar secara daring dalam pembelajaran IPA di kelas VII SMP.

E-modul IPA yang telah dikembang-kan, dapat dilakukan uji praktikalitas dan uji efektifitas di sekolah sebagai salah satu sumber belajar dengan sistem digital yang dapat digunakan di SMP.

\section{Daftar Pustaka}

Abdullah, Syahbanur, R., \& Roza, L. (2020). Pengembangan E-Modul Interaktif Chemistry Magazine Berbasis Kvisoft Flipbook Maker pada Materi Laju Reaksi, Jurnal Zarah, 8(1), 7-13.

Anggraini, D. P. (2019). Penerapan Media Pembelajaran Fisika Menggunakan Modul Cetak dan Modul Elektronik pada Siswa SMA. Jurnal Pendidikan Fisika, 7(1), 1725. DOI: https://doi.org/10.24252/jpf. v7i1.7155

Dahlia, F., Poppy, Y., Supianti, I. I., \& Mira, M. (2019). Pendekatan Saintifik Berbasis eLearning untuk Meningkatkan Kemampuan Berpikir Kreatif Meatematis dan Self-Confidence. Jurnal Analisa, 5(2), 150.

David, M., \& Anass, B. (2020). Determinants of Mobile Learning Acceptance for STEM Education in Rural Areas. Journal Computers \& Education,160(1), 1. DOI: 10.1016/j.compedu.2020.104010

Depdiknas. (2008). Panduan Pengembangan Bahan Ajar. Jakarta: Pusat Kurikulum Balitbang Diknas.

Desi, R., Sri, W., \& Yushardi. (2017). Pengembangan Media Pembelajaran Flipbook pada Materi Gerak Benda di SMP. Jurnal Pembelajaran Fisika, 6(4), 326-332. DOI: https://doi.org/10.19184/ jpf.v6i4.6213 
Hidayatullah, M. S. (2016). Pengembangan Media Pembelajaran Berbasis Flipbook Maker pada Mata Pelajaran Elektronika Dasar di SMKN 1 Sampang, Jurnal Pendidikan Teknik Elektro, 5(1), 83-88.

Indah S., Eko R., \& Henny, J. (2019). Pengembangan Bahan Ajar Elektronik Menggunakan Flip PDF Professional pada Materi Alat-Alat Optik di SMA. Jurnal Kumparan Fisika, 2(3), 145-152.

Joanne, L., Peter, F., Giovanni, L., \& Yvonne. (2020). Development and Impact Evaluation of An e-Learning Radiation Oncology Module. International Journal of Onclology, Biology, Physics, 28(3), 1.

Kemendikbud. (2014). Permendikbud Nomor 103 Tahun 2014 Tentang Pembelajaran Pada Pendidikan Dasar dan Pendidikan Menengah. Jakarta: Kementrian Pendidikan dan Kebudayaan RI.

Kemenristekdikti. (2018). Mempersiapkan SDM Indonesia di Era Revolusi 4.0. Jakarta: Kementrian Riset, Teknologi dan Pendidikan Tinggi RI.

Metriana, V. (2020). Penggunaan e-Modul Sebagai Pembelajaran Daring dalam Menunjang Minat Belajar Siswa Kelas IX. Skripsi, Universitas Pelita Harapan.

Napsawati. (2020). Analisis Situasi Pembelajaran IPA Fisika dengan Metode Daring di Tengah Wabah Covid-19. Karst: Jurnal Pendidikan Fisika dan Terapannya, 3(1), 6-12.

Nina, R. (2016). Pengembangan E-learning dengan Edmodo sebagai Suplemen Pembelajaran Fisika Materi Rangkaian Arus Searah. Skripsi, Pendidikan Fisika Universitas Lampung.

Nur Pajr, M. Hidayat \& Dwi Agus Kurniawan. (2017). Pengembangan $e$-Modul Fisika Berbasis Pendekatan Saintifik pada Materi Rangkaian Listrik untuk Siswa SMP Kelas X. Jurnal Fisika, 1, 1-12.

Nurita, P. (2013). Cara Membuat Media Pembelajaran Online Menggunakan Edmodo. Jurnal Pendidikan Informatika dan Sains, 2( 2).
Nurul, L., Ashari, \& Eko S. K. (2020). Pengembangan e-Modul Fisika untuk Meningkatkan Kemampuan Berpikir Kritis Peserta Didik. JIPS: Jurnal Inovasi Pendidikan Sains, 1(1), 1-7. DOI: https://doi.org/10.37729/jips.v1i1.570

Rebecca, C., \& Jeremy. (2020). Development of An e-Learning Module to Facilitate Student Learning and Outcomes. Journal Teaching and Learning in Nursing, 8(5), 54. DOI: 10.1016/j.teln.2020.10.007

Riduwan. (2015). Skala Pengukuran VariabelVariabel Penelitian. Bandung: Alfabeta.

Robert, M. B. (2009). Instructional Design: The ADDIE Approach. Georgia: Springer.

Seprida, H. (2015). Pemanfaatan e-Learning Berbasis LCMS Moodle Sebagai Media Pembelajaran untuk Mata Kuliah Sistem Informasi Akuntansi. Jurnal Riset Akuntansi dan Bisnis, 15(1), 86-99.

Siti, R., Sihkabuden, \& Susilaningsih. (2018). Penerapan Pendekatan Saintifik pada Mata Pelajaran IPA di MTs Putri Nurul Masyithoh Lumajang. Jurnal KTP, 1(3), 205-212.

Sufairoh. (2016). Pendekatan Saintifik dan Model Pembelajaran K-13. Jurnal Pendidikan Profesional, 5(3), 116-125.

Sukendro, Akhmad, H., Khaeruddin, Boy, I., Syahruddin, Fredrik, A.M., \& Hikmad, H. (2020). Using An Extended Technology Acceptance Model to Understand Students use of e-learning During Covid-19: Indonesian Sport Science Education Context. Journal Heliyon, 6(11), 7-8.

Wahyu, A. (2020). Dampak Covid-19 terhadap Implementasi Pembelajaran Daring di Sekolah Dasar. Jurnal Ilmu Pendidikan, 2(1), 55-61.

Zaharah, Upik, Y., \& Revis, A. (2017). Pengembangan Modul Elektronik dengan Pendekatan Saintifik Materi Sistem Peredaran Darah pada Manusia untuk Siswa Kelas VIII. Jurnal Edu-Sains, 6(1), 26-27. 